\title{
ORFI genetic polymorphisms in geographically distinct HTLV-1 infections
}

\author{
Fernanda Khouri Barreto ${ }^{1,2^{*}}$, Ricardo Khouri ${ }^{1}$, Filipe Ferreira de Almeida Rego ${ }^{1}$, \\ Maria Fernanda de Castro-Amarante ${ }^{3}$, Izabela Bialuk4, Cynthia A Pise-Masison ${ }^{3}$, Bernardo Galvão-Castro ${ }^{1,2}$, \\ Antoine Gessain ${ }^{5}$, Steven Jacobson ${ }^{6}$, Genoveffa Franchini ${ }^{3}$, Luiz Carlos Alcantara Jr ${ }^{1}$
}

From 17th International Conference on Human Retroviruses: HTLV and Related Viruses

Trois Ilets, Martinique. 18-21 June 2015

The region known as $\mathrm{pX}$ in the 3' end of the human T-cell leukemia/lymphoma virus type-1 (HTLV-1) genome contains four overlapping open reading frames (ORF) that encode regulatory proteins. The expression of ORF-I produces the protein $\mathrm{p} 12$ which can be cleavage resulting in the $\mathrm{p} 8$ protein. These proteins interfere with the ability of a biologically active of HTLV-1, influencing at the virus infectivity and persistence. Here, we evaluated whether natural mutations in HTLV-1 ORF-I can influence the proviral load and clinical manifestation of HAM/TSP. For that, we analyzed 1530 HTLV-1 ORFI sequences from different clones of 156 patients with negative or positive diagnosis for HAM/TSP and demonstrated that some mutations may be associated with the outcome of HAM/TSP (C39R, L40F, P45L, S69G and R88K) or with proviral load (P34L and F61L). We further examined the presence of mutations in motifs of HBZ and observed that $\mathrm{P} 45 \mathrm{~L}$ mutation is located within the HBZ nuclear localization signal and was found more frequently between patients with HAM/TSP and high proviral load. This results suggest that some HTLV-1 ORF-I mutations may be associated with the development of HAM/TSP and the proviral load levels.

\section{Authors' details}

${ }^{1}$ Centro de Pesquisa Gonçalo Moniz-Fiocruz, Salvador, Bahia, Brazil. ${ }^{2}$ Escola Bahiana de Medicina e Saúde Pública, Salvador, Bahia, Brazil. ${ }^{3}$ Animal Models and Retroviral Vaccines Section, National Cancer Institute, Bethesda, USA.

${ }^{4}$ Department of General and Experimental Pathology, Medical University of Białystok, Poland. ${ }^{5}$ Unité d'Epidémiologie et Physiopathologie des Virus

Oncogènes, Département de Virologie, Batiment Lwoff, Institut Pasteur, Paris,

* Correspondence: fernanda.khouri@hotmail.com

${ }^{1}$ Centro de Pesquisa Gonçalo Moniz-Fiocruz, Salvador, Bahia, Brazil

Full list of author information is available at the end of the article
France. ${ }^{6}$ Viral Immunology Section, Neuroimmunology Branch, National Institute of Neurological Disorders and Stroke, Bethesda, USA.

Published: 28 August 2015

doi:10.1186/1742-4690-12-S1-P55

Cite this article as: Barreto et al:: ORFI genetic polymorphisms in geographically distinct HTLV-1 infections. Retrovirology 2015 12(Suppl 1): P55
Submit your next manuscript to BioMed Central and take full advantage of:

- Convenient online submission

- Thorough peer review

- No space constraints or color figure charges

- Immediate publication on acceptance

- Inclusion in PubMed, CAS, Scopus and Google Scholar

- Research which is freely available for redistribution

Submit your manuscript at www.biomedcentral.com/submit
() Biomed Central 